Harvard Kennedy School Misinformation Review ${ }^{1}$

April 2021, Volume 2, Special Issue on Propaganda Analysis

Creative Commons Attribution 4.0 International (CC BY 4.0)

Reprints and permissions: misinforeview@hks.harvard.edu

DOI: https://doi.org/10.37016/mr-2020-64

Website: misinforeview.hks.harvard.edu

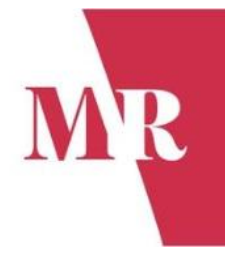

\title{
Propaganda, misinformation, and histories of media techniques
}

This essay argues that the recent scholarship on misinformation and fake news suffers from a lack of historical contextualization. The fact that misinformation scholarship has, by and large, failed to engage with the history of propaganda and with how propaganda has been studied by media and communication researchers is an empirical detriment to it, and serves to make the solutions and remedies to misinformation harder to articulate because the actual problem they are trying to solve is unclear.

Authors: C. W. Anderson

Affiliations: School of Media and Communication, University of Leeds, UK

How to cite: Anderson, C. W. (2021). Propaganda, misinformation, and histories of media techniques. Harvard Kennedy School

(HKS) Misinformation Review, 2(2).

Received: January $25^{\text {th }}, 2021$. Accepted: March $11^{\text {th }}, 2021$. Published: April $15^{\text {th }}, 2021$.

\section{Introduction}

Propaganda has a history and so does research on it. In other words, the mechanisms and methods through which media scholars have sought to understand propaganda-or misinformation, or disinformation, or fake news, or whatever you would like to call it-are themselves historically embedded and carry with them underlying notions of power and causality. To summarize the already quite truncated argument below, the larger conceptual frameworks for understanding information that is understood as "pernicious" in some way can be grouped into four large categories: studies of propaganda, the analysis of ideology and its relationship to culture, notions of conspiracy theory, and finally, concepts of misinformation and its impact. The fact that misinformation scholarship generally proceeds without acknowledging these theoretical frameworks is an empirical detriment to it and serves to make the solutions and remedies to misinformation harder to articulate because the actual problem to be solved is unclear.

The following pages discuss each of these frameworks-propaganda, ideology, conspiracy, and misinformation-before returning to the stakes and implications of these arguments for future research on pernicious media content.

\footnotetext{
${ }^{1}$ A publication of the Shorenstein Center for Media, Politics, and Public Policy, at Harvard University, John F. Kennedy School of Government.
} 


\section{Propaganda and applied research}

The most salient aspect of propaganda research is the fact that it is powerful in terms of resources while at the same time it is often intellectually derided, or at least regularly dismissed. Although there has been a left-wing tradition of propaganda research housed uneasily within the academy (Herman \& Chomsky, 1988; Seldes \& Seldes, 1943), this is not the primary way in which journalism or media messaging has been understood in many journalism schools or mainstream communications departments. This relates, of course, to the institutionalization of journalism and communication studies within the academic enterprise. Within this paradox, we see the greater paradox of communication research as both an applied and a disciplinary field. Propaganda is taken quite seriously by governments, the military, and the foreign service apparatus (Simpson, 1994); at the same time, it has occupied a tenuous conceptual place in most media studies and communications departments, with the dominant intellectual traditions embracing either a "limited effects" notion of what communication "does" or else more concerned with the more slippery concept of ideology (and on that, see more below). There is little doubt that the practical study of the power of messages and the field of communication research grew up together. Summarizing an initially revisionist line of research that has now become accepted within the historiography of the field, Nietzel notes that "from the very beginning, communication research was at least in part designed as an applied science, intended to deliver systematic knowledge that could be used for the business of government to the political authorities." He adds, however, that

this context also had its limits, for by the end of the decade, communication research had become established at American universities and lost much of its dependence on state funds. Furthermore, it had become increasingly clear that communication scientists could not necessarily deliver knowledge to the political authorities that could serve as a pattern for political acting (Simpson, 1994 pp. 88-89). From then on, politics and communication science parted ways. Many of the approaches and techniques which seemed innovative and even revolutionary in the 1940s and early 1950s, promising a magic key to managing propaganda activities and controlling public opinion, became routine fields of work, and institutions like the USIA carried out much of this kind of research themselves. (Nietzel, 2016, p. 66)

It is important to note that this parting of ways did not mean that no one in the United States and the Soviet Union was studying propaganda. American government records document that, in inflationadjusted terms, total funding for the United States Information Agency (USIA) rose from $\$ 1.2$ billion in 1955 to $\$ 1.7$ billion in 1999, shortly before its functions were absorbed into the United States Department of State. And this was dwarfed by Soviet spending, which spent more money jamming Western Radio transmissions alone than the United States did in its entire propaganda budget. Media effects research in the form of propaganda studies was a big and well-funded business. It was simply not treated as such within the traditional academy (Zollman, 2019). It is also important to note that this does not mean that no one in academia studies propaganda or the effect of government messages on willing or unwilling recipients, particularly in fields like health communication (also quite well-funded). These more academic studies, however, were tempered by the generally accepted fact that there existed no decontextualized, universal laws of communication that could render media messages easily useable by interested actors.

\section{Ideology, economics, and false consciousness}

If academics have been less interested than governments and health scientists in analyzing the role played by propaganda in the formation of public opinion, what has the academy worried about instead when it comes to the study of pernicious messages and their role in public life? One dominant, deeply contested line of study has revolved around the concept of ideology. As defined by Raymond Williams in his 
wonderful Keywords, ideology refers to an interlocking set of ideas, beliefs, concepts, or philosophical principles that are naturalized, taken for granted, or regarded as self-evident by various segments of society. Three controversial and interrelated principles then follow. First, ideology-particularly in its Marxist version-carries with it the implication that these ideas are somehow deceptive or disassociated from what actually exists. "Ideology is then abstract and false thought, in a sense directly related to the original conservative use but with the alternative-knowledge of real material conditions and relationships-differently stated" (Williams, 1976). Second, in all versions of Marxism, ideology is related to economic conditions in some fashion, with material reality, the economics of a situation, usually dominant and helping give birth to ideological precepts. In common Marxist terminology, this is usually described as the relationship between the base (economics and material conditions) and the superstructure (the realm of concepts, culture, and ideas). Third and finally, it is possible that different segments of society will have different ideologies, differences that are based in part on their position within the class structure of that society.

Western Marxism in general (Anderson, 1976) and Antonio Gramsci in particular helped take these concepts and put them on the agenda of media and communications scholars by attaching more importance to "the superstructure" (and within it, media messages and cultural industries) than was the case in earlier Marxist thought. Journalism and "the media" thus play a major role in creating and maintaining ideology and thus perpetuating the deception that underlies ideological operations. In the study of the relationship between the media and ideology, "pernicious messages" obviously mean something different than they do in research on propaganda-a more structural, subtle, reinforcing, invisible, and materially dependent set of messages than is usually the case in propaganda analysis. Perhaps most importantly, little research on media and communication understands ideology in terms of "discrete falsehoods and erroneous belief," preferring to focus on processes of deep structural misrecognition that serves dominant economic interests (Corner, 2001, p. 526). This obviously marks a difference in emphasis as compared to most propaganda research.

Much like in the study of propaganda, real-world developments have also had an impact on the academic analysis of media ideology. The collapse of communism in the 1980s and 1990s and the rise of neoliberal governance obviously has played a major role in these changes. Although only one amongst a great many debates about the status of ideology in a post-Marxist communications context, the exchange between Corner $(2001,2016)$ and Downey (2008; Downey et al., 2014) is useful for understanding how scholars have dealt with the relationship between large macro-economic and geopolitical changes in the world and fashions of research within the academy. Regardless of whether concepts of ideology are likely to return to fashion, any analysis of misinformation that is consonant with this tradition must keep in mind the relationship between class and culture, the outstanding and open question of "false consciousness," and the key scholarly insight that ideological analysis is less concerned with false messages than it is with questions of structural misrecognition and the implications this might have for the maintenance of hegemony.

\section{Postmodern conspiracy}

Theorizing pernicious media content as a "conspiracy" theory is less common than either of the two perspectives discussed above. Certainly, conspiratorial media as an explanatory factor for political pathology has something of a post-Marxist (and indeed, postmodern) aura. Nevertheless, there was a period in the 1990s and early 2000s when some of the most interesting notions of conspiracy theories were analyzed in academic work, and it seems hard to deny that much of this literature would be relevant to the current emergence of the "QAnon" cult, the misinformation that is said to drive it, and other even more exotic notions of elites conspiring against the public. 
Frederic Jameson has penned remarks on conspiracy theory that represent the starting point for much current writing on the conspiratorial mindset, although an earlier and interrelated vein of scholarship can be found in the work of American writers such as Hofstadter (1964) and Rogin (1986). "Conspiracy is the poor person's cognitive mapping in the postmodern age," Jameson writes, "it is a degraded figure of the total logic of late capital, a desperate attempt to represent the latter's system" (Jameson, 1991). If "postmodernism," in Jameson's terms, is marked by a skepticism toward metanarratives, then conspiracy theory is the only narrative system available to explain the various deformations of the capitalist system. As Horn and Rabinach put it:

The broad interest taken by cultural studies in popular conspiracy theories mostly adopted Jameson's view and regards them as the wrong answers to the right questions. Showing the symptoms of disorientation and loss of social transparency, conspiracy theorists are seen as the disenfranchised "poor in spirit," who, for lack of a real understanding of the world they live in, come up with paranoid systems of world explanation. (Horn \& Rabinach, 2008)

Other thinkers, many of them operating from a perch within media studies and communications departments, have tried to take conspiracy theories more seriously (Bratich, 2008; Fenster, 2008; Pratt, 2003; Melley, 2008). The key question for all of these thinkers lies within the debate discussed in the previous section, the degree to which "real material interests" lie behind systems of ideological mystification and whether audiences themselves bear any responsibility for their own predicament. In general, writers sympathetic to Jameson have tended to maintain a Marxist perspective in which conspiracy represents a pastiche of hegemonic overthrow, thus rendering it just another form of ideological false consciousness. Theorists less taken with Marxist categories see conspiracy as an entirely rational (though incorrect) response to conditions of late modernity or even as potentially liberatory. Writers emphasizing that pernicious media content tends to fuel a conspiratorial mindset often emphasize the mediated aspects of information rather than the economics that lie behind these mediations. Both ideological analysis and academic writings on conspiracy theory argue that there is a gap between "what seems to be going on" and "what is actually going on," and that this gap is maintained and widened by pernicious media messages. Research on ideology tends to see the purpose of pernicious media content as having an ultimately material source that is rooted in "real interests," while research on conspiracies plays down these class aspects and questions whether any real interests exist that go beyond the exercise of political power.

\section{The needs of informationally ill communities}

The current thinking in misinformation studies owes something to all these approaches. But it owes an even more profound debt to two perspectives on information and journalism that emerged in the early 2000 s, both of which are indebted to an "ecosystemic" perspective on information flows. One perspective sees information organizations and their audiences as approximating a natural ecosystem, in which different media providers contribute equally to the health of an information environment, which then leads to healthy citizens. The second perspective analyzes the flows of messages as they travel across an information environment, with messages becoming reshaped and distorted as they travel across an information network.

Both of these perspectives owe a debt to the notion of the "informational citizen" that was popular around the turn of the century and that is best represented by the 2009 Knight Foundation report The Information Needs of Communities (Knight Foundation, 2009). This report pioneered the idea that communities were informational communities whose political health depended in large part on the quality of information these communities ingested. Additional reports by The Knight Foundation, the Pew 
Foundation, and this author (Anderson, 2010) looked at how messages circulated across these communities, and how their transformation impacted community health.

It is a short step from these ecosystemic notions to a view of misinformation that sees it as a pollutant or even a virus (Anderson, 2020), one whose presence in a community turns it toward sickness or even political derangement. My argument here is that the current misinformation perspective owes less to its predecessors (with one key exception that I will discuss below) and more to concepts of information that were common at the turn of the century. The major difference between the concept of misinformation and earlier notions of informationally healthy citizens lies in the fact that the normative standard by which health is understood within information studies is crypto-normative. Where writings about journalism and ecosystemic health were openly liberal in nature and embraced notions of a rational, autonomous citizenry who just needed the right inputs in order to produce the right outputs, misinformation studies has a tendency to embrace liberal behavioralism without embracing a liberal political theory. What the political theory of misinformation studies is, in the end, deeply unclear.

\section{Conclusion}

I wrote earlier that misinformation studies owed more to notions of journalism from the turn of the century than it did to earlier traditions of theorizing. There is one exception to this, however. Misinformation studies, like propaganda analysis, is a radically de-structured notion of what information does. Buried within analysis of pernicious information there is

A powerful cultural contradiction - the need to understand and explain social influence versus a rigid intolerance of the sociological and Marxist perspectives that could provide the theoretical basis for such an understanding. Brainwashing, after all, is ultimately a theory of ideology in the crude Marxian sense of "false consciousness." Yet the concept of brainwashing was the brainchild of thinkers profoundly hostile to Marxism not only to its economic assumptions but also to its emphasis on structural, rather than individual, causality. (Melley, 2008, p. 149)

For misinformation studies to grow in such a way that allows it to take its place among important academic theories of media and communication, several things must be done. The field needs to be more conscious of its own history, particularly its historical conceptual predecessors. It needs to more deeply interrogate its informational-agentic concept of what pernicious media content does, and perhaps find room in its arsenal for Marxist notions of hegemony or poststructuralist concepts of conspiracy. Finally, it needs to more openly advance its normative agenda, and indeed, take a normative position on what a good information environment would look like from the point of view of political theory. If this environment is a liberal one, so be it. But this position needs to be stated clearly.

Of course, misinformation studies need not worry about its academic bona fides at all. As the opening pages of this Commentary have shown, propaganda research was only briefly taken seriously as an important academic field. This did not stop it from being funded by the U.S. government to the tune of 1.5 billion dollars a year. While it is unlikely that media research will ever see that kind of investment again, at least by an American government, let's not forget that geopolitical Great Power conflict has not disappeared in the four years that Donald Trump was the American president. Powerful state forces in Western society will have their own needs, and their own demands, for misinformation research. It is up to the scholarly community to decide how they will react to these temptations. 


\section{Bibliography}

Anderson, C. W. (2010). Journalistic networks and the diffusion of local news: The brief, happy news life of the Francisville Four. Political Communication, 27(3), 289-309. https://doi.org/10.1080/10584609.2010.496710

Anderson, C. W. (2020, August 10). Fake news is not a virus: On platforms and their effects. Communication Theory, 31(1), 42-61. https://doi.org/10.1093/ct/qtaa008

Anderson, P. (1976). Considerations on Western Marxism. Verso.

Bratich, J. Z. (2008). Conspiracy panics: Political rationality and popular culture. State University of New York Press.

Corner, J. (2001). 'Ideology': A note on conceptual salvage. Media, Culture \& Society, 23(4), 525-533. https://doi.org/10.1177/016344301023004006

Corner, J. (2016). 'Ideology' and media research. Media, Culture \& Society, 38(2), 265-273. https://doi.org/10.1177/0163443715610923

Downey, J. (2008). Recognition and renewal of ideology critique. In D. Hesmondhaigh \& J. Toynbee (Eds.), The media and social theory (pp. 59-74). Routledge.

Downey, J., Titley, G., \& Toynbee, J. (2014). Ideology critique: The challenge for media studies. Media, Culture \& Society, 36(6), 878-887. https://doi.org/10.1177/0163443714536113

Fenster (2008). Conspiracy theories: Secrecy and power in American culture (Rev. ed.). University of Minnesota Press.

Herman, E., \& Chomsky, N. (1988). Manufacturing consent: The political economy of the mass media. Pantheon Books.

Hofstadter, R. (1964, November). The paranoid style in American politics. Harper's Magazine.

Horn, E., \& Rabinach, A. (2008). Introduction. In E. Horn (Ed.), Dark powers: Conspiracies and conspiracy theory in history and literature (pp. 1-8), New German Critique, 35(1). https://doi.org/10.1215/0094033x-2007-015

Jameson, F. (1991). Postmodernism, or, the cultural logic of late capitalism. Duke University Press.

The Knight Foundation. (2009). Informing communities: Sustaining democracy in the digital age. https://knightfoundation.org/wp-content/uploads/2019/06/Knight Commission Report Informing Communities.pdf

Melley, T. (2008). Brainwashed! Conspiracy theory and ideology in postwar United States. New German Critique, 35(1), 145-164. https://doi.org/10.1215/0094033X-2007-023

Nietzel, B. (2016). Propaganda, psychological warfare and communication research in the USA and the Soviet Union during the Cold War. History of the Human Sciences, 29(4-5), 59-76. https://doi.org/10.1177/0952695116667881

Pratt, R. (2003). Theorizing conspiracy. Theory and Society, 32, 255-271. https://doi.org/10.1023/A:1023996501425

Rogin, M. P. (1986). The countersubversive tradition in American politics. Berkeley Journal of Sociology, 31, 133. https://www.jstor.org/stable/41035372

Seldes, G., \& Seldes, H. (1943). Facts and fascism. In Fact.

Simpson, C. (1994). Science of coercion: Communication research and psychological warfare, 19451960. Oxford University Press.

Williams, R. (1976). Keywords: A vocabulary of culture and society. Oxford University Press.

Zollmann, F. (2019). Bringing propaganda back into news media studies. Critical Sociology, 45(3), 329345. https://doi.org/10.1177/0896920517731134 


\section{Copyright}

This is an open access article distributed under the terms of the Creative Commons Attribution License, which permits unrestricted use, distribution, and reproduction in any medium, provided that the original author and source are properly credited. 